\title{
LEGAL AND INSTITUTIONAL COVERAGE TO STREET CHILDREN IN KHYBER PAKHTUNKHWA
}

\author{
Adnan Ashraf*, Basharat Hussain $\uparrow$ \& \\ Faseeh Ullah
}

\begin{abstract}
The numbers of street children are estimated to be 1.5 million in Pakistan. Being an urban phenomenon, the pool is increasing day by day and simultaneously increases manifold vulnerabilities to violence, abuse, exploitation, etc. Khyber Pakhtunkhwa has established legal and institutional structure to respond towards street children. However, the effective use of these institutions is yet to be made. There is a dearth of information on the subject; this study was conducted to evaluate the perception of Child Protection Experts regarding protection, welfare and rehabilitation system for street children in Peshawar. A Qualitative study using a structured interview format with predefined themes was conducted in 20 Child Protection Experts (KPCWC, CPUs, UNICEF, Social Welfare, Zamung Kor, Dost Welfare Foundation and SPARC). This study is based on Urie Bronfenbrenner's ecological systems theory focuses on the quality and context of the child's environment. Most of the experts explained that legislative framework is present to protect the street children rights; however, there are several legal and Institutional loopholes and a need of strong political and government determination to respond to the subject of street children by strengthening the legal and institutional framework that require government commitment to respond in a sustainable manner rather than Adhoc basis.
\end{abstract}

Keywords: Street child; Child protection experts/officer; legal and institutional framework; child protection units, welfare and rehabilitation system.

\footnotetext{
* PhD Scholar, Department of Social Work, University of Peshawar.

${ }^{\dagger}$ Chairman, Department of Criminology, University of Peshawar.

$\$$ M.Phil Scholar, Department of Psychology, Islamia College Peshawar.
} 


\section{Introduction}

The term street children was first used by Henry Mayhew in 1851, however, it came into common use only after the adoption by the United Nations (UN) year of Child in 1979 (Tetteh, 2018). The UN has defined the term street children"e to include "any boy or girl" for whom the street in the widest sense of the word has become his or her habitual dwelling and basis of income, and who is ineffectively protected, overseen, or directed by responsible adults" (World Childhood Foundation, 2014).

The United Nations International Children's Emergency Fund has defined two categories of street children. The first category is "children on the street". These children are spending considerable amount of time on street. However, they are mostly living in their places of abodes with their families. The second category of street children is called as children "off the street". These children are working and living routinely on street. Children from this category have zero to little family links. (UNICEF., 1996)

Street children is a global phenomenon (Alawiye-Adams \& Afolabi, 2013). According to World Information on the Geological Appropriation, there are millions of street children working and living on the street. It is estimated that 100 to 140 million children are roaming on the streets globally. It was stated that South America is hosting 40 million street children; Asia is hosting 25 million, Africa 10 million while 25 million street children can be found in the Western and Eastern Europe (Abdullah et al., 2014).

In Pakistan, $70 \%$ of populations live in rural areas, and it is thought that mostly street children across the country are in transition from rural to urban areas, living and surviving on the town streets (Alvi, 2018). Indigenous research studies on street children shows that $93 \%$ of children are on the street, who keep contact with family and return to their abode at night while $7 \%$ are "off the street" (Ali, Shahab, Ushijima, \& de Muynck, 2004; G. Khan, 2013). The gender segregation of street children reveal that $80 \%$ are boys where median age group is 9-13 years and generally between 5-18 years (Ali \& De Muynck, 2005).

Socio-economic problems in the wider society are causing an uneven rise in the street children population worldwide and thus supporting the growth of different evils in the society which has adverse effects on children (Scheper-Hughes, 2004).

The published literature on the street children has found poverty and parental negligence as the root cause of the problem. Furthermore, some children are also joining the street life due to love for liberty, desperation, while others are due to loss of parents, war, economic instability, domestic violence, neglect, physical and mental abuse (Nasir, Khalid, \& Shoukat, 2014). 
Street children are vulnerable to number of social, physical and psychological harms. They are mostly dwelling in unhygienic conditions and relying on unhealthy food which is detrimental to their health (Panicker, 1993). They are routinely harassed, abused and exploited (M. Khan, 2007).

They are frequently involved in hazardous form of labour and in other ill-mannered activities such as criminal acts, drug addiction. Street children in Pakistan are living in an environment which is harmful to their wellbeing and frequently involved in hazardous form of labour and impertinent activities (Rafi, Ali, \& Aslam, 2012). According to the (Mughal, 2008) approximately $90 \%$ of children on or off the street are preys of sodomy, physical and sexual abuse at the hands of their elders or older children of their own flocks. Furthermore, street children were mostly drug addicted.

Pakistan has ratified several international conventions on the protection of the basic rights of children. Among these conventions, the most vibrant and vital convention is the United Nations Convention on the Rights of the Child (UNCRC) of 1989. The pressure of Convention on the Rights of the Child and other international conventions have conditioned Pakistan to enact laws in conformity with the UNCRC and devise an Institutional mechanism for the protection, welfare and development of street children. In this regard, few steps were taken regarding policy and legislative reforms. Some of the key steps being made by the government including the establishment of Khyber Pakhtunkhwa Child Protection and Welfare Commission at provincial level and Child Protection Units at districts under the Khyber Pakhtunkhwa Children Protection and Welfare Act, 2010. The Directorate of Social Welfare, Special Education and Women Empowerment Khyber Pakhtunkhwa has established several Beggar Homes and Welfare Homes for destitute children. Establishment of Zamung Kor for the rehabilitation, education and reintegration of street children into the mainstream society.

All the federating units have established institutional and legal framework to protect the rights of the children. Khyber Pakhtunkhwa has established legal and institutional structure to respond towards street children. However, the effective use of these institutions is yet to be made. There is a dearth of information on the subject; this study was conducted to evaluate the perception of Child Protection Experts regarding protection, welfare and rehabilitation system for street children in Peshawar. This research will be helpful to the policy makers to overcome the legal and institutional loopholes and to devise an efficient and effective child friendly environment which are conducive for the proper growth and development of the street children.

\section{Objectives of the Study}

- To evaluate the legal framework for street children in Khyber Pakhtunkhwa 
- To evaluate the institutional framework for street children in Khyber Pakhtunkhwa.

\section{Methodology}

Qualitative study design was used, and 20 Child protection experts from Government bodies (Child Protection and Welfare Commission, Department of Social Welfare, Welfare Homes, Zamung Kor), leading child rights body UNICEF and NGOs (SPARC, Dost Welfare Foundation) were selected using purposive sampling technique with the help of an interview guide.

For validation questionnaire was piloted in two child protection experts. There was only slight modification in order and language of the questions. Feedback prior using it for the core study was also requested.

The interviews were conducted using English language with their formal approval and assurance of confidentiality. In the first stage, a rapport was built with the respondents. After the rapport building stage, the researcher started asking the topic related questions. Cell phone sound recorder was used for recording the interviews.

All the recorded interviews were transcribed and then thematically analysed. Approval to conduct the study was granted by the ethical review committee of University of Peshawar (UOP) and written informed consent was obtained from all participants.

\section{Theoretical Framework}

This research study was based on the theoretical framework of Urie Bronfenbrenner's 1979 Ecological systems theory. It is Ecological viewpoint which embolden individual to understand the holistic environment of a child. The violations of child rights are the outcome of the multifaceted interaction of individual affiliated with the communal, cultural and ecological elements. To know and dealt with the rights of children, these aspects must be pondered in terms of their presence and communication at all levels. The focus of the model is the "child" which is surrounded by four levels. The first level is that of the micro-system, including instant ecological contiguous the child and those people with whom the child interrelates like family, peer, and school. Meso system is the second level, which includes the contact that flow within the micro-system, for example, the relationships between the family and Children's Services, the family and support networks, or the family and the school. The third system is Exo system which defines the structure that does not affect the child directly, but still affect the child's life such as neighbourhoods and school environment. Lastly the macro system denotes to the communal and cultural atmosphere which all the systems exist like communal and political standard and the legal system. 


\section{Results and Discussion}

\section{Participants Characteristics}

Among the 20 child protection experts, 18 were male. All the child protection experts have Post-graduation degree in various subjects like Sociology, Social Work, Anthropology, Psychology, Public Policy and Management, Political Science, Project Management, LLB and one of the experts was a PhD scholar of Sociology. Two-third of the sample had a total experience of 12-15 years, while 5 experts had 7 years and one had 24 years of total experience.

\section{Rights of Street Children in Khyber Pakhtunkhwa (KP), Pakistan}

Child rights situation is deplorable in Pakistan and far away from satisfactory in the KP as well and it is apparent from the fact that occurrences of child rights violations are documented daily (SPARC, 2012). Majority of the experts discussed that unfortunately, in Pakistan children are deprived of their basic rights, children are out of schools, wandering on the street, involved in illegal activities, sexually abused and exploitation by the overall society in various shapes.

The Constitution of 1973 guaranteed basic rights to all human beings irrespective of gender, age, religion and caste. The state is responsible for the arrangement and provision of the right of education, health, recreation, protection of life, freedom of expression, etc. This is consistent with the study results investigating the localities considered to be the hot spots of street children in Lahore (Khalid, Nasir, \& Rehman, 2014).

An estimated 2.6 million children are out of schools, whereas 1.5 million are engaged in some type of child labour and $4 \%$ are under ten years of age. Mostly they are employed in harmful condition unfavourable to their overall health (Daily Express Tribune, 2012).

In this part of the world the violations of the rights of the children on the rise. Children are exposed to numerous detrimental circumstances and are on edge of exploitation and abuse (Akhunzada, Ullah, \& Khan, 2016).

All experts illustrate the situation of children in common and street children particularly facing a wide range of protection issues. They are mostly weak, dependent and deprived of their rights. Street life poses serious threats to the street children such as sexual abuse, emotional abuse, drug addiction, and child beggary which are hampering the survival, development, welfare and protection of street children.

\section{Impact of United Nations Convention on the Rights of Children (UNCRC)}

All experts discussed that Convention on the rights of the Child is a holistic document towards protection, welfare and rehabilitation of children. 
To protect and respond to child protection issues, Pakistan has come up with various global treaties, the UNCRC is of great importance as it frames the policy guidelines on children's issues at national level (Jabeen, 2016).

Expert No. 07 shared that

Article 19 of UNCRC is recognized as the "policy guideline for all child protection and welfare legislation which provides protection against abuse, exploitation and neglect, similarly, its cover economic, social, cultural and civil rights of street children”.

Although the Committee on (CRC) binds signatory states to guarantee protection of child rights irrespective of any prejudice, but generally street children in the country continue to be among the most vulnerable population.

However, on parallel side after the timespan of 3 decades CRC come into force, Pakistan has come up with definite legal and institutional developments prior to devolution of powers and particularly post $18^{\text {th }}$ constitutional amendment, which shifted the subject to provincial control and KP has undertaken various legal and institutional developments.

Similarly, Expert No. 16 discussed that

"Instead of legal developments in the provinces, the situation of child rights protection, survival and development are still miserable. Provinces have substantial autonomy in policy and lawmaking. Therefore, development in enactment of legislation towards child protection differs from province to province".

\section{Khyber Pakhtunkhwa Child Protection and Welfare Act, 2010}

All Experts explained the most recent development in the province was enactment of "The Khyber Pakhtunkhwa Child Protection and Welfare Act on September 21, 2010. This law aims to provide care, protection, maintenance, welfare, training, education, rehabilitation and reintegration to children at risk in Khyber Pakhtunkhwa.

Expert No. 18 added that

"Under the law a provincial focal point for the supervision, coordination and management of child protection subject was established named 'Child Protection \& Welfare Commission' at Peshawar. The law mandated formation of Child Protection Units across the province, Child Protection Committees; establish or recognize Child Protection Institutes; Child Protection Welfare Fund, and Child Protection Courts. Part VIII of the law deals with offences and penalties. The law deals with civil and criminal matters, The Section "d" define "Child at Risk" and cover an extensive assortment of children in need of protection, counting with orphans, street children, children with disabilities, children living in brothels 
or with prostitutes, children in conflict with the law, children living in extreme poverty, beggars, child laborers, etc".

It is worth noting that KP has exclusive child protection legislation such as the KPCPW Act, 2010, Khyber-Pakhtunkhwa Borstal Institutions Act 2012, Juvenile Justice System Ordinance (JJSO), (Daily Express Tribune, Sep 07,2014).

Expert No. 12 shared that

"Coverage of the law has been extended to provincially administer tribal areas (PATA), and KPCPW Amendment Act, 2016 has also been enacted".

\section{Child Protection and Welfare Commission Outreach}

Regarding the CPWC performance, Expert No. 17 stated that "Commission has mandated to establish CPU s, throughout the province, but unfortunately, since its establishment in 2011 till 2018, twelve CPUs were established. The most unfortunate situation is of CPU Peshawar which was non-operational from 2015 due to administrative issues whereas the remaining 11 districts were donor supported till 2018".

It was stated that Pakistani culture of charity compounded the mission of the KPCPWC, and trouble with delivery of facilities through some strict standards of eligibility (McMillan, 2013).

Child Protection Expert's believed that one of the matters linked within the prevailing administrative structure, for instance, in Punjab, child protection comes under the domain of Home department, whereas in KP it falls under the administrative control of the Department of Social Welfare, which is more acquainted with welfare rather than rights.

Expert No. 10 shared that

"KPCPW Act 2010 asked for establishing "Child Protection \& Welfare fund". The fund was utilized for the protection, welfare, education, training, maintenance, rehabilitation and reintegration of children at risk. The district CPUs was provided this fund and utilized in the field of social support where orphan, destitute, street children were provided with needed services, but unfortunately, from 2015 this fund was no more available which adversely affect its impact".

While the principle department Social Welfare is not showing any seriousness in regularization of the CPWC and CPUs. Compare to Punjab, budget for child protection and welfare bureau, CPWC are allocated with grant in-aid of 10 million only. 
All experts expressed concern on the closure of CPU Peshawar from last 5 years and similarly 11 remaining district points were closed from January 2019 till date.

Expert No. 13 commented

"CPWC comes up with some good achievements, including establishment of CPUs, Child Protection Case Management Information System (CPCMIS), and extension of law to the PATA, from Peshawar High Court Notified District \& Session Judge to perform their role as a Child Protection Court".

Expert No. 15 explained that in Khyber Pakhtunkhwa Child Protection is mixed up with social protection or child welfare and as per data analysis of CPCMIS which reveals that, CPUs have overwhelmingly dealing matters of child access to health, education and disability instead of protection issues of children.

Most of the Experts agreed that under section 3(d), in the Province, KPCPWC is mandated to review laws and regulations relating to the status of children, but unfortunately, CPWC has not come up with a single reviewed law on the subject matter which is a great failure.

Expert No. 02 explained that

"CPUs established helpline 1121 at district for easy access to report rights violation and asked for needed services”.

Besides Expert No. 19 discussed that UNCRC optional protocol was signed by Pakistan in 2000 which cover the matters confronting by street children like of child prostitution, child pornography and Sale of Children. Though, KPCPW Act not discusses the matters which were practicing of confronting matters stated above. One of the critiques of KPCPW Act 2010, it's not bringing uniformity in the age of a child being a signatory of CRC. For example, in a case of protecting child labour, The Employment of Children Act 1991 define child under 14 years, whereas The Shops and Establishments Ordinance, 1969 define 12 years and the most recent legislation in the province was "The Khyber Pakhtunkhwa Prohibition of Employment of Children Act, 2015" which define 14 years. Additionally, Expert No. 11 described that

"CPUs also contributed in the child rights protection and welfare.

$C P U$ installed child helpline 1121 for the reporting, contacting and availing needed services, awareness raising of local communities, local Child Protection Committees (CPC, s), District Coordination Working Group (DCWG) as a notified committee for coordination, reporting and referrals of child protection and welfare cases".

It was stated by Jabeen, in direction to function proficiently and maintainable, the focus of CPUs must be towards protection of street 
children from violence, neglect, abuse and exploitation, which comes under the state obligation as agreed in CRC Article 19 (Jabeen, 2016).

Expert No. 04 mentioned that

"Under section 9 (2), of the KP CPW Act, 2010; the role of Child Protection Officer (CPO), is to assist the District Social Welfare Officer in respect of CPUs which is hindering the autonomy of the CPO. Furthermore, Act mentions that CPO has the legal authority of inspecting any Child Protection Institution, organization or building and monitors its training, shelter, living conditions, livelihood means, record etc; but unfortunately, till date there are no rules for practicing this power".

Regarding the importance of standard operating procedure (SoPs) for operationalization of programs, Expert No. 03 added that it's the blueprint which guides the program implementation.

In 2016, KP Child protection and welfare rules were notified, which provides a framework for KPCPWC, CPUs, child protection institute and Zamung Kor model institute for street children.

Expert No. 09 shared that

"Consultant drafted and submitted SoPs but its notification is yet to be proceed. Similarly, on part of Ngo's there is dearth of SoPs, although with an intention of goodwill some of the organization draft some policy guideline but its true implementation is missing".

Generally, street children were believed to be involved in un-social activities and be part of some criminal/gangs, for this purpose, the KP Govt has exclusive legislation for such Juvenile children and under KP Borstal Institutions Act asked for establishment of Borstal Institutions to rehabilitate and social reintegrate these children but unfortunately, instead of two Borstal Institutions building at Bannu and Mansehra, none of the Borstal Institutions are functional which raise questions on the implementation of this legal document.

\section{Khyber Pakhtunkhwa Prohibition of Employment of Children Act, 2015}

Instead of legislative and institutional coverage their involvement in harmful occupations are alarming. Expert No. 14 expressed that

"Despite the existence of child labour laws 'Employment of Children Act 1991" and "Prohibition of Employment of Children Act, 2015" which defines child age 14 years and allowing them to work under specific conditions. But the act yet to be implemented in true spirit, the situation is quite miserable with no monitoring mechanism, involvement in hazardous labouring which badly affect children overall health. Government constitute a Committee named 
'Khyber Pakhtunkhwa Coordination Committee on Child Labour'.

The Committee role is to do proper policy, planning and implementation to eradicate the involvement of child labours in hazardous occupations.

All experts illustrate that being a ratified member of International labour organisation (ILO) conventions 138 and 182, dealing with minimum age of admission to employment and worst forms of child labour, Pakistan has very poor implementation. According to the Article 11 of the Constitution of 1973, none of the child below 14 years of age shall be permissible in any factory, mine or any other harmful engagement.

Expert No. 06, commented that

"Labour inspector has the legal authority of monitoring factories, shops and ensures adoption of protective measures in the best interest of children".

\section{Khyber Pakhtunkhwa Free Compulsory Primary and Secondary Education Act, 2017}

All the experts discoursed that in pursuance of Article 25 (A) of the Constitution, KP had come up with an explicit law to provide free and compulsory education to all children between age 5-16 years., School attendance authority are constituted at every school to ensure regular attendance of school.

The law authorize school authority to issue order to the parents to assure regular attendance and if fail to comply with order issued under section (3) of section (5) shall be on conviction before a judicial magistrate shall be punishable with imprisonment which may be extend for a month of fine of hundred rupees per day (KPCPSE Act, 2017). For the welfare of the school children, the Government must establish Taleem Fund which consists of grants made by federal government, voluntary contributions from Philanthropist, students, alumni, parents and district govt (KPCPSE Act, 2017).

All Experts agreed that its true implementation in letter and spirit is yet to be made.

\section{Institutional Arrangements by Department of Social Welfare}

No sincere efforts have ever been made to quantify the street children, and regulate its nature and scope (Nasir et al., 2014). In KP Child rights and protection comes under the Department of Social Welfare. Institutional setup has existence at Welfare home for destitute children at Peshawar, Kohat, Abbottabad, Bannu and Dera Ismail Khan and Welfare home for beggar's children in Peshawar. The Services includes free residential care, food, medical care services through referral partners and formal education along with vocational skills program. But unfortunately, the quality of services and its effectiveness is a question mark. 
Legal contradiction was observed despite the existence of contemporary law (KPCPW Act, 2010). In practice Welfare home for beggar's children are still operating under the repealed laws The West-Pakistan Vagrancy Ordinance, 1958 and the North-West Frontier Province Orphanages (Supervision and Control) Act, 1976.

Expert No. 05 reveals the

"Pathetic condition of these institutes with a tendency of welfare approach whereas absence of any rehabilitation and reintegration plan. There is absence of professional staff and primarily psychologist and social worker".

Institutional mechanism of beggar and welfare homes, its environment, services delivery, staff capacity, rehabilitation and reintegration plan are nonexistence.

Expert No. 01 pointed that

"The institution itself is prone to abuse, torture and exploitation. Besides, the provincial govt. established Zamung-Kor Model Institute for Street children with objectives to provide safe and protected environment to street children. On this initiative, Expert pleased with establishment of the Institute but on other side, they said that it is operational on grand-in-aid basis with merely a capacity of 126 children".

\section{National Centre(s) for Rehabilitation of Child Labour}

Bait-Ul-Maal is running nineteen centres in KP for rehabilitation and reintegration of street children of aged 5-14 years and providing services and facilities including centre-based education, clothing, shoes and stipend.

All the experts expressed dissatisfaction on the impact of these rehabilitation centres for various reasons like simply a welfare model with no clear intervention strategy, guidelines and rehabilitation plan. Simply it creates dependency among children to avail the offered package of the program and that's all.

9.1 Dost Gulona Kor: Dost foundation in collaboration with department of social welfare implemented project for street children in Peshawar. Dost Gulona Kor \& Day Care Centre is rendering services to the On the Street and Off the Street Children; these children include runaway children also. It provides transit shelter to protect children from violence, abuse, exploitation and offer education, psycho-social counselling, food, accommodation, clothes, health, family identification and reunification services.

Most of the experts raised question on its sustainability, legal mandate and absence of SoPs. 
9.2 Day Care Centre for Street Children: SPARC implemented street children project for On the Street children in Peshawar. The centre registered child scavengers, garbage collector children and provides them non-formal education like Life Skills Basic Education (LSBE), Psycho social counselling and food. According to Expert no. 17, to combat street children needs joint venture of Government and NGOs on regular basis.

\section{Conclusion}

Street children phenomena need a comprehensive way forward to cope with it. Though the legal and institutional framework is available but there is a need of strong political and government will to respond to the subject of street children by strengthening the legal and institutional framework that require government commitment to respond in a sustainable manner rather than Adhoc basis. The most unfortunate situation was the non-operational CPUs which raised a question towards the subject importance on Government behalf.

Ecological framework enlighten the study from a holistic perspective of its four levels, and all subject experts expressed that micro-system of family and peer influence is a nurturing and development stage for a child and due to non-satisfactory role at the stage, exposure to street life happen, followed by Meso system between the family, Children's Services and support networks build a foundation base for child expression and participation. All the experts expressed that Exo system of neighbourhoods and school environment is a socialization platform provides a protective platform for children motivation, lastly the macro system represents the overall communal and cultural atmosphere where children are exposed to numerous threats and the contributions of micro, meso and exo convert the child into a social being.

In Khyber Pakhtunkhwa Street children are consistently abused. Instead of CRC, National, Provincial legislation and institutionalization, province lack the true and accurate statistics of street children, adhoc bases programs/projects of child protection are non-functional from years. According to the Constitution and UNCRC all children are entitled to have equal rights of education, health, speech, services, care, protection from abuse, exploitation, violence etc.

\section{Policy Recommendations}

The province has exclusive legislative and institutional mechanism but the approach of donor project based transforms it into dependence and secondary consideration. The Department of Social welfare has departmental infrastructure across the province, but a commitment towards regularization 
and budgetary support to operationalize district child protection units is of utmost importance and program focus should be towards protection in comparison to welfare and charity to cater the needs of survial and development of street children.

\section{Disclaimer}

The paper has been extracted from my M.Phil thesis submitted to University of Peshawar.

It was presented at $1^{\text {st }}$ International Conference of Social Work "Theme"'(Social Work Education \&Practice: Global Agenda \& Local Challenges) organized by Department of Social Work in Colloboration with Univeristy of Calgary, Canada and Community Worldwide Services (CWS), from $3^{\text {rd }}$ to $5^{\text {th }}$ March 2020 at University of Peshawar.

\section{References}

Abdullah, M.A., Basharat, Z., Lodhi, O., Wazir, M.H.K., Khan, H.T., Sattar, N.Y., \& Zahid, A. (2014). A qualitative exploration of Pakistan's street children, as a consequence of the poverty-disease cycle. Infectious diseases of poverty, 3(1), 1-8.

Akhunzada, Z.U., Ullah, F., \& Khan, M.A. (2016). child rights issues in Khyber Pakhtunkhwa: a Qualitative Study. New Horizons, 10(2), 55.

Alawiye-Adams, A., \& Afolabi, B. (2013). Street Children Phenomenon in Nigeria: The Challenges and Way Forward. SSRN Electronic Journal. doi: $10.2139 /$ ssrn. 2325114

Ali, M., \& De Muynck, A. (2005). Illness incidence and health seeking behaviour among street children in Rawalpindi and Islamabad, Pakistan-a qualitative study. Child: care, health and development, 31(5), 525-532.

Ali, M., Shahab, S., Ushijima, H., \& de Muynck, A. (2004). Street children in Pakistan: A situational analysis of social conditions and nutritional status. Social Science \& Medicine, 59(8), 1707-1717.

Alvi, M.H. (2018). Difference in the Population Size between Rural and Urban Areas of Pakistan. https://mpra.ub.uni-muenchen.de/90054/.

Daily Express Tribune. (2012). 1.5m Child Labour's in KP: SPARC. . Retrieved from http://tribune.com.pk/story/392580/1-5m-childlabourers-in Khyber Pakhtunkhwa sparc/

Daily Express Tribune. (Sep 07,2014). Keeping them Safe: Government Urged to Enact Pending Laws on Child Rights. 
Jabeen, T. (2016). Child protection legislation in Pakistan: Bringing international child rights obligations and local values together. Pakistan Journal of Criminology, 8(3), 16.

Khalid, A., Nasir, M., \& Rehman, S. (2014). A Study to Identify the Hot Spots of Street Children in Lahore. Pakistan Vision, 16(1), 40-55.

Khan, G. (2013). Street children and rehabilitation services in Pakistan. Journal of Behavioural Sciences, 23(2), 117.

Khan, M. (2007). Street children: solvent abuse to solve problems. SPARC's Discourse, 28, 19-21.

Mughal, A. (2008). Street children: The state of Pakistan's children 2007. Society for the Protection of the Rights of the Child, 16-20.

Nasir, M., Khalid, A., \& Shoukat, A. (2014). Maslow theory of human development and emergence of street children phenomenon in Pakistan. Pakistan Vision, 15(2), 98.

Panicker, R. (1993). Study on the situation of street children in six cities of India: Major findings. Street and Working Children, 8, 1-2.

Rafi, S., Ali, M., \& Aslam, M.A. (2012). The problem of street children: case study of Sargodha City. American International Journal of Contemporary Research, 2(2), 194-197.

Scheper-Hughes, N. (2004). Dangerous and endangered youth: social structures and determinants of violence. Annals of the New York Academy of Sciences, 1036(1), 13-46.

SPARC. (2012). Concept note on the Status of Child Related Legislation in the Post 18th Constitutional Amendment Scenario and Responsibilities of Provincial Government KP. Retrieved March 15, 2017, from www.sparcpk.org/KP.doc

Tetteh, W. (2018). The Phenomenon of Children Beggars on the Streets of Accra. (Master of Philosophy, dissertation), University of Ghana.

UNICEF. (1996). The State of the World's Children 2005-Official Summary: UNICEF.

World Childhood Foundation. (2014). What is a street child? Retrieved February 25, 2021, from https://www.childhoodusa.org/news/2014/9/1/what-is-a-street-child\# 